\title{
Photoreception for Circadian, Neuroendocrine, and Neurobehavioral Regulation
}

\author{
John P. Hanifin and George C. Brainard \\ Department of Neurology, Thomas Jefferson University
}

\begin{abstract}
In the art and science of lighting, four traditional objectives have been to provide light that: 1) is optimum for visual performance; 2) is visually comfortable; 3 ) permits aesthetic appreciation of the space; and 4) conserves energy. Over the past 25 years, it has been demonstrated that there are nonvisual, systemic effects of light in healthy humans. Furthermore, light has been used to successfully treat patients with selected affective and sleep disorders as well as healthy individuals who have circadian disruption due to shift work, transcontinental jet travel, or space flight. Recently, there has been an upheaval in the understanding of photoreceptive input to the circadian system of humans and other mammals. Analytical action spectra in rodents, primates, and humans have identified $446-484 \mathrm{~nm}$ (predominantly the blue part of the spectrum) as the most potent wavelength region for neuroendocrine, circadian, and neurobehavioral responses. Those studies suggested that a novel photosensory system, distinct from the visual rods and cones, is primarily responsible for this regulation. Studies have now shown that this new photosensory system is based on a small population of widely dispersed retinal ganglion cells that are intrinsically responsive to light, and project to the suprachiasmatic nuclei and other nonvisual centers in the brain. These light-sensitive retinal ganglion cells contain melanopsin, a vitamin A photopigment that mediates the cellular phototransduction cascade. Although light detection for circadian and neuroendocrine phototransduction seems to be mediated principally by a novel photosensory system in the eye, the classic rod and cone photoreceptors appear to play a role as well. These findings are important in understanding how humans adapt to lighting conditions in modern society and will provide the basis for major changes in future architectural lighting strategies. J Physiol Anthropol 26(2): 87-94, 2007 http://www.jstage.jst.go.jp/browse/jpa2
\end{abstract}

[DOI: 10.2114/jpa2.26.87]

Keywords: action spectra, circadian, melanopsin, melatonin, neuroendocrine, photopigment, photoreception, pineal gland, light therapy, lighting

\section{Introduction}

Light is a potent biological and therapeutic force which is fundamental to life on our planet. Living things vary in their capacity to use visible and near-visible radiant energy from the sun for survival but the vast majority of organisms owe their existence to using solar light as an energy source. Despite this incontroversial fact, what is known about light's effects on humankind is still in its infancy. Traditionally, the design of artificial lighting has adhered to providing illumination that gives the best possible input to the visual system while addressing aesthetic and ecological needs of the space being illuminated. Integrating the recent discovery of a new sensory system in the human eye that detects environmental light for neurobehavioral regulation is the challenge facing lighting engineers, architects, and scientists.

\section{Phototransduction and Action Spectra for Circadian, Neuroendocrine, and Neurobehavioral Responses}

There is a basic principle shared by all species in their ability to respond to light stimuli: all photobiological responses are mediated by organic molecules that absorb light quanta and then undergo physical-chemical changes. These light-induced changes subsequently evoke broader physiological responses within the organism. This process is termed phototransduction, and the specific molecular complexes that absorb light energy to initiate photobiological responses are called photopigments. As a rule, these photoactive molecules do not absorb energy equally across the electromagnetic spectrum. Photopigments have their own characteristic wavelength absorption spectrum that depends on their atomic structure (Grossweiner, 1989; Horspool and Song, 1994; Coohill, 1991; 1999). A photopigment's pattern of wavelength sensitivity, or its absorbance spectrum, is like a fingerprint-it is unique to that molecular complex.

In the field of photobiology, an action spectrum is one of the principal tools for identifying the photopigment that initiates a light-induced response. An action spectrum is the relative response of an organism to different wavelengths of visible and 
near-visible electromagnetic radiation. Photobiologists have evolved a set of refined approaches for determining action spectra that are applicable to all light-responsive organisms (Grossweiner, 1989; Horspool and Song, 1994; Coohill, 1991; 1999). There are two types of action spectra: polychromatic and analytic (Coohill, 1999). In general, when researchers initially study light-sensitive biological reactions, they begin by determining polychromatic action spectra. Such action spectra are developed using broader bandwidth light stimuli that have half-peak bandwidths greater than $15-20 \mathrm{~nm}$. Although these action spectra are valuable for identifying interactions of biological response to multiple wavelengths and guiding more sophisticated analytic action spectra, they have limited utility for identifying peak sensitivities of specific photopigments that initiate photobiological responses (Coohill, 1999).

Earlier action spectrum studies on neuroendocrine and circadian responses to light utilized polychromatic stimuli. Across this set of publications, both humans and rodents were studied in terms of pineal melatonin synthesis, circadian phase shifting, or photoperiodic responses (Brainard and Hanifin, 2005 for review). The polychromatic action spectra are consistent in suggesting that the general spectral region between $450 \mathrm{~nm}$ and $550 \mathrm{~nm}$ provides the strongest stimulation of circadian and neuroendocrine responses in mammals with little to no responsiveness to the longer wavelength end of the visible spectrum. Long wavelength light of sufficient high intensity, however, can acutely suppress melatonin, as well as phase shift or entrain circadian rhythms in both rodents and humans (Brainard and Hanifin, 2005; Hanifin et al., 2006).

Some of the earlier polychromatic action spectra indicated peak wavelengths that suggest circadian responses might not be mediated by the classic rod and cone photoreceptors. Similarly, early studies with blind animals with destruction of retinal photoreceptors due to prolonged light exposure raised the possibility that neither the rods nor the cones used for vision participate in regulating the circadian and neuroendocrine systems (Pevet et al., 1984; Webb et al., 1985). Despite profound loss of photoreceptors and vision, light detection for circadian and photoperiodic regulation was preserved. A decade of research in the 1990s on mice with hereditary retinal disorders $(r d / r d$ and $r d s / r d s)$ and on transgenic coneless $(\mathrm{cl})$ mice have shown that these animals still exhibit normal light-induced melatonin suppression and circadian locomotor phase shifts despite a nearly total loss of classical visual photoreceptors (Foster et al., 1991; Lucas et al., 1999; Freedman et al., 1999). Similarly, studies performed on humans with no conscious perception of light demonstrated intact circadian responses to light (Czeisler et al., 1995; Klerman et al., 2002). A field study run on visually impaired individuals showed that those who had no visual light perception had abnormal circadian rhythms as measured by urinary 6-sulfatoxymelatonin (aMT6s), a metabolite of melatonin, compared to blind subjects who retained a degree of visual light perception (Lockley et al., 1997). Color vision deficient subjects studied for light suppression of melatonin suggested that a normal three-cone system is not required for this response (Ruberg et al., 1996). The data emerging from those studies made it increasingly clear that there was a non-rod, non-cone photoreceptor at work in circadian phototransduction.

In the mid 1980s, circadian and neuroendocrine researchers began employing monochromatic wavelengths and increasingly sophisticated photobiological techniques for determining analytic action spectra. Analytical action spectra are determined comparing the effects of two or more monochromatic light stimuli with half-peak bandwidths of $15-20 \mathrm{~nm}$ or less. It is optimal to develop analytic action spectra by establishing a set of dose-response curves (fluenceresponse curves) at different wavelengths for a specific biological response. An action spectrum is then formed by plotting the reciprocal of incident photons required to produce the biological response versus wavelength (Grossweiner, 1989; Horspool and Song, 1994; Coohill, 1991; 1999). Recent analytical action spectra demonstrating the wavelength sensitivity of various physiological responses are summarized in Table 1. It is important to note that all of the action spectra in Table 1 fit the data to opsin nomograms with relatively high coefficients of correlation and indicate shorter wavelength peak sensitivities $\left(\lambda_{\max }\right)$ in the blue portion of the visible spectrum. Across those studies, the calculated $\lambda_{\max }$ indicates peak photosensitivity of $459 \mathrm{~nm}$ to $484 \mathrm{~nm}$. Together, all of those studies suggested that a novel photoreceptor system was involved in circadian and neurobehavioral phototransduction mediated by the eye. While these analytical action spectra were being developed, other work was clarifying the biochemical and anatomical nature of this novel sensory system.

\section{The Discovery of Melanopsin and Intrinsically Photosensitive Retinal Ganglion Cells}

Melanopsin, a molecule found originally in frog skin lightsensitive melanophore cells was an early leading candidate for the mammalian circadian photopigment, since it is expressed in anatomical areas where a nonvisual photoreceptor is likely to be present (Rollag, 1996; Provencio et al., 1998). Melanopsin also shares predicted structural similarities with all known opsins, including seven transmembrane proteins. Provencio and colleagues (2000) identified melanopsin in the inner human retina, cloned both human and mouse melanopsin, and showed a large sequence homology to invertebrate opsins. This structural similarity to invertebrate opsins would makes sense in allowing the photopigment to regenerate distant from chromophore-regenerating tissues, such as the retinal pigment epithelium (RPE).

Melanopsin-containing ganglion cells with extended neural networks were identified in the rodent retina (Berson et al., 2002; Provencio et al., 2002; Hattar et al., 2002; Panda et al., 2002) as well as human (Provencio et al., 2000; Rollag et al., 2003; Hannibal et al., 2004) and primate inner retinas (Dacey 
et al., 2005). In rodents, melanopsin has been found in a specific subtype of intrinsically photosensitive retinal ganglion cells (ipRGC) which project to a number of nonvisual nuclei, including the suprachiasmatic nuclei, intergeniculate leaflets, olivary pretectal nuclei, preoptic nuclei, and subparaventricular zones (Gooley et al., 2001, 2003; Hattar et al., 2002; Hannibal et al., 2002, 2004). These ipRGCs respond to light on their own when separated physically or blocked by drugs from receiving input from other neurons (Berson et al., 2002; Dacey et al., 2005).

In the past few years, studies have provided convincing evidence that melanopsin is a functional circadian photopigment in ipRGCs. In blind humans, melanopsin expression was maintained in the retinas of people with severe retinal diseases (Hannibal et al., 2004). Three recent studies have provided even more compelling evidence that melanopsin is the photopigment responsible for ipRGC phototransduction (Melyan et al., 2005; Qiu et al., 2005; Panda et al., 2005). When nonphotosensitive cells such as mouse paraneurons, human kidney cells, and Xenopus oocytes are transfected with the human or mouse melanopsin genes, each cell type becomes light-sensitive. The discovery of melanopsin and ipRGCs is a crowning scientific achievement, has led to a revolution in our understanding of circadian photoreception, and is beginning to guide scientists into new uses of light for circadian, sleep, and other disorders.

\section{The Use of Light for Clinical and Nonclinical Applications}

Seasonal Affective Disorder (SAD) is the most studied clinical condition that employs light as a therapeutic agent. $\mathrm{SAD}$ is a type of depression in which symptoms occur yearly during the shorter days of autumn and winter and remit during the longer days of spring and summer. Symptoms include low mood, reduced interest, decreased concentration, low energy and fatigue, increased need for sleep, increased appetite, and carbohydrate cravings with consequential weight gain (Lewy et al., 1982; Rosenthal et al., 1984; Lam and Levitt, 1999). Light therapy has proven to be an effective therapeutic intervention for patients of all ages with SAD (Terman et al., 1998; Eastman et al., 1998; Lam and Levitt, 1999; Terman et al., 2001). Patients vary in their responsiveness to light therapy and the current standard practice is a trial of 10,000 lux white fluorescent light for 30-60 minutes in the morning (Lam and Levitt, 1999; Terman et al., 2001). Recently, a preliminary Phase I study on SAD patients testing narrow bandwidth blue light was significantly better than dimmer red light in reversing symptoms of major depression with a seasonal pattern; however, the optimum blend of wavelengths for treating this disorder is still not known (Glickman et al., 2006). Although a majority of studies employing light therapy have focused on treatment of SAD, additional clinical applications of light treatment have been explored, including light for the treatment of non-seasonal depression, various sleep disorders, menstrual- cycle related problems, bulimia nervosa, and senile dementia (Kripke, 1998; Terman et al., 1995; Parry et al., 1989; Kripke, 1993; Lam et al., 1994; Forbes et al., 2004; Tuunainen et al., 2005).

Light therapy for use in resolving problems associated with intercontinental travel and shift work are currently being evaluated. While the body readjusts its biological clock to a new time zone, many people experience symptoms such as daytime sleepiness, nighttime insomnia, gastrointestinal distress, irritability, mild depression, and confusion (Boulos et al., 1995; Revell and Eastman, 2005). The average period of readjustment may range from three to twelve days, depending on the direction of travel and the number of time zones that have been spanned. Similar to intercontinental travelers, shift workers are also forced to make changes to their usual sleep and wake times. It has been estimated that approximately $20 \%$ of workers in industrialized nations participate in some form of shift work (US Congress, 1991; Eastman et al., 1995). It has been observed that shift workers have a higher incidence of cardiovascular disease and gastrointestinal distress as well as cognitive and psychological problems. Many researchers hypothesize that these ailments are caused, in part, by difficulty adjusting to a night shift or rotating schedules. A number of studies have shown that properly timed exposure to light and darkness may enhance workers' circadian systems to adapt to shift schedules (Czeisler et al., 1986; Lewy et al., 1987; Eastman et al., 1995; Czeisler et al., 1990; Minors et al., 1991, Revell and Eastman, 2005). Recently, studies have specifically tested monochromatic and polychromatic short wavelength (blue) light for improved efficacy compared to longer wavelength monochromatic light for inducing circadian phase shifts in healthy humans under laboratory conditions (Lockley et al., 2003; Warman et al., 2003; Revell et al., 2005).

As with shift work applications, light is being tested as a countermeasure for disruption of circadian rhythms and sleepwake patterns in astronauts during long duration space flight (Czeisler et al., 1991; Whitson et al., 1995; Stewart and Eastman, 1996; Dijk et al., 2001; Wright et al., 2001). Disturbed circadian rhythms and altered sleep-wake patterns are major risk factors for the health and safety of astronauts (NASA, 2004). Associated behavioral changes include decreased alertness, diminished concentration, and performance decrements, all of which can compromise the safety of personnel and the objectives of space missions. Preliminary studies of astronauts and ground control workers have shown light treatment to be an effective tool for supporting circadian entrainment (Czeisler et al., 1991; Whitson et al., 1995; Stewart and Eastman, 1996; Dijk et al., 2001; Wright et al., 2001). Ongoing research continues to investigate how to optimize light as a countermeasure for circadian and sleep disruption in space flight missions (Fucci et al., 2005).

Bright light exposure appears to have an acute stimulatory "alerting" effect on healthy humans. An early study showed that subjects working a continuous 30-hour shift demonstrated 
Table 1 Analytical action spectra studies for circadian, neuroendocrine and ocular responses.

\begin{tabular}{|c|c|c|c|}
\hline Species & Response & $\operatorname{Peak}\left(\lambda_{\mathrm{Max}}\right)$ & Citation \\
\hline Mouse & Circadian & 480 & Yoshimura and Ebihara, 1996 \\
\hline$r d / r d$ & Phase-Shifting & & \\
\hline Human & Melatonin Suppression & 459 & Thapan et al., 2001 \\
\hline Mouse & Pupillary & 479 & Lucas et al., 2001 \\
\hline$r d / r d$ & Light Reflexes & & \\
\hline \multirow[t]{2}{*}{ Rat } & Ganglion Cell & 484 & Berson et al., 2002 \\
\hline & Depolarization & & \\
\hline Mouse & Circadian & 481 & Hattar et al., 2003 \\
\hline$r d / r d c l$ & Phase-Shifting & & \\
\hline Monkey & Ganglion Cell Depolarization & 482 & Dacey et al., 2005 \\
\hline
\end{tabular}

Table 2 Correlated color temperature (CCT) effects on circadian and neuroendocrine responses.

\begin{tabular}{lll}
\hline \multicolumn{1}{c}{ Citation } & \multicolumn{1}{c}{ CCT Comparisons } & \multicolumn{1}{c}{ Parameters Measured } \\
\hline Deguchi and Sato, 1992 & $7,500 \mathrm{~K}, 5,000 \mathrm{~K}, 3,000 \mathrm{~K}$ & Reaction Time \\
Mukae and Sato, 1992 & $6,700 \mathrm{~K}, 5,000 \mathrm{~K}, 3,000 \mathrm{~K}$ & Heart Rate Variability \\
Morita and Tokura, 1998 & $6,500 \mathrm{~K}, 3,000 \mathrm{~K}$ & Core Temperature, Melatonin \\
Noguchi and Sakaguchi, 1999 & $5,000 \mathrm{~K}, 3,000 \mathrm{~K}$ & Heart Rate Variability, EEG, Subjective Drowsiness \\
Yasukouchi et al., 2000 & $7,500 \mathrm{~K}, 5,000 \mathrm{~K}, 3,000 \mathrm{~K}$ & Skin Temperature, Rectal Temperature, Expired Gas \\
Kozaki et al., 2005 & $6,700 \mathrm{~K}, 5,000 \mathrm{~K}, 3,000 \mathrm{~K}$ & Polysomnography, EEG, EOG, EMG \\
Sato et al., 2005 & $6,480 \mathrm{~K}, 3,150 \mathrm{~K}$ & Rectal Temperature, Salivary Melatonin \\
Yasukouchi and Ishibashi, 2005 & $7,500 \mathrm{~K}, 6,700 \mathrm{~K}, 5,000 \mathrm{~K}, 3,000 \mathrm{~K}$ & Arousal Level, Heart Rate Variability, Blood Pressure, Body \\
& & Temperature Reg., Sleep Architecture \\
\hline
\end{tabular}

enhanced behavioral and cognitive performance as well as significant differences in body temperature, melatonin and cortisol levels when working under 3,000 lux of white light as compared to a dimmer light exposure of 100 lux (French et al., 1990). Several other experiments have demonstrated the immediate alerting effects of bright light on humans (Badia et al., 1991; Campbell et al., 1995; Brainard et al., 1996; Boyce et al., 1997; Cajochen et al., 2000). Further testing of the alerting effects of short wavelength light has shown greater potency than longer wavelength light for alerting effects as measured by subjective and objective behavioral assessments, as well as polysomnography, heart rate, and thermoregulation in healthy human subjects (Lockley et al., 2006; Cajochen et al., 2005; Revell et al., 2006). These studies suggest that short wavelength light is more potent than long wavelength light for acutely enhancing alertness.

Over the last decade scientists have discovered many neurobehavioral changes based on the correlated color temperature of polychromatic, fluorescent lights. Specifically, it was found that lights with a higher color temperature evoke stronger melatonin suppression compared to lamps with a lower color temperature in healthy humans (Morita and Tokura, 1998; Sato et al., 2005). Additionally, higher color temperature fluorescent lamps have a more potent effect on core body temperature than low color temperature lamps
(Morita and Tokura, 1998; Yasukouchi et al., 2000). Further, blood pressure and EEG frequency have been shown to increase under a high color temperature as compared to lower color temperatures (Noguchi and Sakaguchi, 1999; Yasukouchi and Ishibashi, 2005). When examining the effects of illumination prior to sleep, deep sleep (S4) was reduced under a high color temperature compared to a low color temperature during the first half of sleep (Kozaki et al., 2005). Table 2 summarizes some of the published studies which have probed these effects of color temperature on human physiology. Together, this literature consistently demonstrates that higher correlated color temperature lamps induce stronger neurobehavioral effects than lower correlated color temperature lamps in healthy subjects. Such results are consistent with the recently completed analytical action spectra shown in Table 1.

Given the peak sensitivities observed in studies using monochromatic light (Table 1), it is logical to predict that polychromatic light sources will evoke stronger circadian, neuroendocrine, and neurobehavioral responses if they are enriched in the blue portion of the visible spectrum. The literature capsulated in Table 2 appears to support that concept.

Figure 1 shows two normalized spectral power distributions (SPDs) from two polychromatic light sources: atmospheric daylight and an incandescent light bulb. If these complex light 

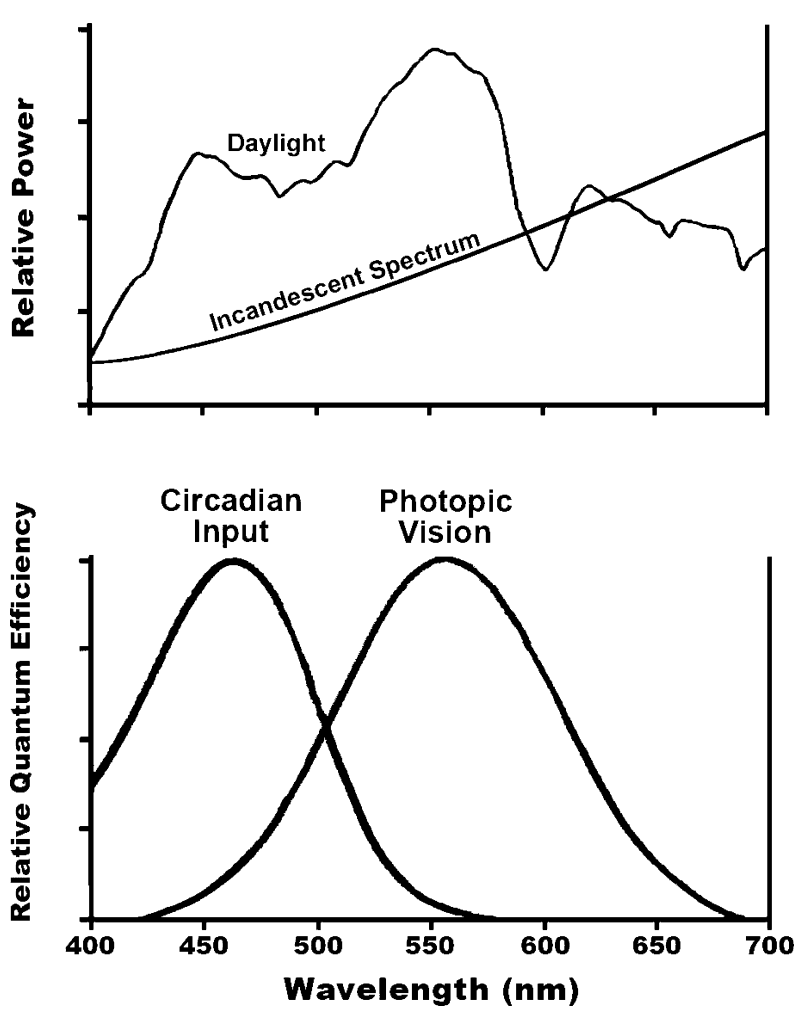

Fig. 1 The top graph provides a normalized spectral power distribution (SPD) for daylight and incandescent lamplight. It is important to note that typical incandescent lamplight is much weaker than daylight but normalizing the SPDs permits a comparison of wavelength distributions. The daylight SPD was measured on a clear day in Philadelphia at 3:00 PM in July, 2006. The incandescent SPD is derived from Figure $2-5$ of the Handbook of the Illuminating Engineering Society of North America (IESNA, 2000). The bottom right graph illustrates the relative wavelength sensitivity of the threecone photopic visual system with a peak sensitivity of $555 \mathrm{~nm}$. The bottom left graph represents a model of wavelength sensitivity for mammalian circadian, neuroendocrine, and neurobehavioral responses that appear to be regulated by ipRGCs. This model is based on the published action spectra shown in Table 1, and may have a peak sensitivity between 446 and $484 \mathrm{~nm}$ (Brainard and Hanifin, 2005).

sources were compared on an equal photon density basis, it might be expected that daylight would be more powerful than the incandescent source in eliciting neurobehavioral responses. Ultimately, future studies are needed to compare a wide variety of natural and artificial polychromatic light sources to determine if this concept is generally true.

\section{Conclusions}

The seminal discovery of a new photosensory system in the human eye opens the door for further development of light therapy for clinical and non-clinical applications as well as potential use in general architecture. Much more work must be done, however, before there is any certainty about the optimum blend of wavelengths for these types of applications.

Careful characterization of the spectral power distribution of the polychromatic stimuli that later permits calculation of the relevant spectrally weighted values needs to be employed in all future studies. Ultimately a new, dedicated metric for quantifying light for circadian, neuroendocrine, and neurobehavioral regulation will need to be determined. Such a metric must be based on a clear understanding of the ipRGC photoreceptors, their interactions with classical rod and cone photoreceptors, and their behavior in complex dynamically illuminated environments. Integrating this rapidly expanding branch of neuroscience with the fields of lighting engineering and architecture will be the next challenge facing photobiologists into the 21 st century.

Acknowledgments The authors gratefully appreciate the editorial and technical support of Benjamin Warfield and Michael Jablonski. This work was supported, in part, by grants from NIH RO1NS36590, National Space Biomedical Research Institute through NASA NCC 9-58, the Keller Companies Inc., and the Philadelphia Section of the Illuminating Engineering Society.

\section{References}

Badia P, Myers B, Boecker M, Culpepper J (1991) Bright light effects on body temperature, alertness, EEG, and behavior. Physiol Behav 50: 583-588

Berson DM, Dunn FA, Takao M (2002) Phototransduction by retinal ganglion cells that set the circadian clock. Science 295: 1070-1073

Boulos Z, Campbell SS, Lewy AJ, Terman M, Dijk D-J, Eastman CI (1995) Light treatment for sleep disorders: consensus report. VII. jet lag. J Biol Rhythms 10: 167-176

Boyce P, Beckstead J, Eklund N, Strobel R, Rea M (1997) Lighting the graveyard shift: the influence of a daylightsimulating sky on the task performance and mood of nightshift workers. Lighting Res Technol 29: 105-134

Brainard GC, Hanifin JP, Hannon PR, Gibson W, French J, Rollag MD (1996) The biological and behavioral effects of light in humans: from basic physiology to application. In MF Holick, EG Jung, eds. Biologic Effects of Light 1995. Walter de Gruyter \& Co., New York, 380-397

Brainard GC, Hanifin JP, Greeson JM, Byrne B, Glickman G, Gerner E, Rollag MD (2001) Action spectrum for melatonin regulation in humans: evidence for a novel circadian photoreceptor. J Neurosci 21: 6405-6412

Brainard GC, Hanifin JP 2005 Photons, clocks and consciousness. J Biol Rhythms 20: 314-325

Cajochen C, Zeitzer JM, Czeisler CA, Dijk D-J (2000) Doseresponse relationship for light intensity and ocular and electroencephalographic correlates of human alertness. Behav Brain Res 115: 75-83

Cajochen C, Munch M, Kobialka S, Krauchi K, Steiner R, Oelhafen P, Orgul S, Wirz-Justice A (2005) High sensitivity of human melatonin, alertness, thermoregulation and heart rate to short wavelength light. J Clin Endocrinol Metab 90: 


\section{$1311-1316$}

Campbell SS, Dijk D-J, Boulos Z, Eastman CI, Lewy AJ, Terman M (1995) Light treatment for sleep disorders: consensus report. III. alerting and activating effects. J Biol Rhythms 10: 129-132

Coohill TP (1991) Action spectra again? Photochem Photobiol 54: $859-870$

Coohill TP (1999) Photobiological action spectra-what do they mean? In $\mathrm{R}$ Matthes, D Sliney, S Didomenico, $\mathrm{P}$ Murray, R Phillips, S Wengraitis, eds. Measurements of Optical Radiation Hazards. ICNIRP, Munchen, Germany, 27-39

Czeisler CA, Allan JS, Strogatz SH, Ronda JM, Sanchez R, Rios CD, Freitag WO, Richardson GS, Kronauer RE (1986) Bright light resets the human circadian pacemaker independent of the timing of the sleep-wake cycle. Science 233: 667-671

Czeisler CA, Johnson MP, Duffy JF, Brown EN, Ronda JM, Kronauer RE (1990) Exposure to bright light and darkness to treat physiologic maladaptation to night work. N Engl J Med 322: 1253-1259

Czeisler CA, Chiasera AJ, Duffy JF (1991) Research on sleep, circadian rhythms and aging: applications to manned spaceflight. Exp Gerontol 26: 217-232

Czeisler CA, Shanahan TL, Klerman EB, Martens H, Brotman DJ, Emens JS, Klein T, Rizzo JF, III (1995) Suppression of melatonin secretion in some blind patients by exposure to bright light. N Engl J Med 332: 6-11

Dacey DM, Liao H-W, Peterson BB, Robinson FR, Smith VC, Pokorny J, Yau K-W, Gamlin PD (2005) Melanopsinexpressing ganglion cells in primate retina signal colour and irradiance and project to the LGN. Nature 433: 749-754

Deguchi T, Sato M (1992) The effect of color temperature of lighting sources on mental activity level. Ann Physiol Anthrop 11:37-43

Dijk DJ, Neri DF, Wyatt JK, Ronda JM, Riel E, A. R-D, Hughes RJ, Elliott AR, Prisk GK, West JB, Czeisler CA (2001) Sleep, performance, circadian rhythms, and lightdark cycles during two space shuttle flights. Am J Physiol 281: R1647-R1664

Eastman CI, Boulos Z, Terman M, Campbell SS, Dijk D-J, Lewy AJ (1995) Light treatment for sleep disorders: consensus report. VI. shift work. J Biol Rhythms 10: $157-164$

Eastman CI, Young MA, Fogg LF, Liu L, Meaden PM (1998) Bright light treatment of winter depression: a placebocontrolled trial. Arch Gen Psychiatry 55: 883-889

Forbes D, Morgan DG, Bangma J, Peacock S, Pelletier N, Adamson J (2004) Light therapy for managing sleep, behaviour, mood disturbances in dementia. The Cochrane Database of Systematic Reviews 2: CD003946

Foster RG, Provencio I, Hudson D, Fiske S, DeGrip W, Menaker M (1991) Circadian photoreception in the retinally degenerate mouse (rd/rd). J Comp Physiol [A] 169: 39-50

Freedman MS, Lucas RJ, Soni B, von Schantz M, Munoz M,
David-Gray Z, Foster RG (1999) Regulation of mammalian circadian behavior by non-rod, non-cone, ocular photoreceptors. Science 284: 502-504

French J, Hannon P, Brainard GC (1990) Effects of bright illuminance on body temperature and human performance. Annu Rev Chronopharmacol 7: 37-40

Fucci, RL, Gardner J, Hanifin JP, Jasser S, Byrne B, Gerner E, Rollag M, Brainard GC 2005 Toward optimizing lighting as a countermeasure to sleep and circadian disruption in space flight. Acta Astronautica 56: 1017-1024

Glickman G, Byrne B, Pineda C, Hauck WW, Brainard GC (2006) Light therapy for Seasonal Affective Disorder with blue narrow-band light-emitting diodes (LED). Biol Psychiatry 59: 502-507

Gooley JJ, Lu J, Chou TC, Scammell TE, Saper CB (2001) Melanopsin in cell of origin of the retinohypothalamic tract. Nature Neurosci 4: 1165

Gooley JJ, Lu J, Fischer D, Saper CB (2003) A broad role for melanopsin in nonvisual photoreception. J Neurosci 23: 7093-7106

Grossweiner LI (1989) Photophysics. In KC Smith, ed. The Science of Photobiology. Plenum Press, New York, 1-45

Hanifin JP, Stewart KT, Smith P, Tanner R, Rollag M, Brainard GC (2006) High intensity red light suppresses melatonin. Chronobiol Int 23: 251-268

Hankins MW, Lucas RJ (2002) The primary visual pathway in humans is regulated according to long-term light exposure through the action of a nonclassical photopigment. Curr Biol 12: $191-198$

Hannibal J, Fahrenkrug J (2002) Melanopsin: a novel photopigment involved in the photoentrainment of the brain's biological clock? Ann Med 34: 401-407

Hannibal J, Hindersson P, Ostergaard J, Georg B, Heegaard S, Larsen PJ, Fahrenkrug J (2004) Melanopsin is expressed in PACAP-containing retinal ganglion cells of the human retinohypothalamic tract. Invest Ophthalmol Vis Sci 45: 4202-4209

Hattar S, Liao H-W, Takao M, Berson DM, Yau K-W (2002) Melanopsin-containing retinal ganglion cells: architecture, projections, and intrinsic photosensitivity. Science 295: $1065-1070$

Hattar S, Lucas RJ, Mrosovsky N, Thompson S, Douglas RH, Hankins MW, Lem J, Biel M, Hofmann F, Foster RG, Yau $\mathrm{K}-\mathrm{W}$ (2003) Melanopsin and rod-cone photoreceptive systems account for all major accessory visual functions in mice. Nature 424: 76-81

Horspool WM, Song P-S, eds (1994) Organic photochemistry and photobiology, CRC Press, New York, 1-1636

Illuminating Engineering Society of North America (2000) Lighting Handbook: Reference \& Application, Illuminating Engineering Society of North America, New York

Klerman EB, Shanahan TL, Brotman DJ, Rimmer DW, Emens JS, Rizzo JF, Czeisler CA (2002) Photic resetting of the human circadian pacemaker in the absence of conscious vision. J Biol Rhythms 17: 548-555 
Kozaki T, Kitamura S, Higashihara Y, Ishibashi K, Noguchi H, Yasukouchi A (2005) Effect of color temperature of light sources on slow-wave sleep. J Physiol Anthropol Appl Human Sci 24: 183-186

Kripke DF (1993) Light regulation of the menstrual cycle. In L Wetterberg, ed. Light and Biological Rhythms in Man. Pergamon Press, Stockholm, 305-312

Kripke DF (1998) Light treatment for nonseasonal depression: speed, efficacy, combined treatment. J Affective Disord 49: 109-117

Lam RW, Levitt AJ, eds (1999) Canadian consensus guidelines for the treatment of Seasonal Affective Disorder, Clinical and Academic Publishing, Vancouver, British Columbia, 1-160

Lam RW, Goldner EM, Solyom L, Remick RA (1994) A controlled study of light therapy for bulimia nervosa. Am J Psychiatry 151: 744-750

Lewy AJ, Kern HE, Rosenthal NE, Wehr TA (1982) Bright artificial light treatment of a manic-depressive patient with a seasonal mood cycle. Am J Psychiatry 139: 1496-1498

Lewy AJ, Sack RL, Miller LS, Hoban TM (1987) Antidepressant and circadian phase-shifting effects of light. Science 235: 352-354

Lockley SW, Skene DJ, Arendt J, Tabandeh H, Bird AC, Defrace R (1997) Relationship between melatonin rhythms and visual loss in the blind. J Clin Endocrinol Metab 82: 3763-3770

Lockley SW, Brainard GC, Czeisler CA (2003) High sensitivity of the human circadian melatonin rhythm to resetting by short wavelength light. J Clin Endocrinol Metab 88: 4502-4505.

Lockley SW, Evans EE, Scheer FA, Brainard GC, Czeisler CA, Aeschbach D (2006) Short-wavelength sensitivity for the direct effects of light on alertness, vigilance, and the waking electroencephalogram in humans. Sleep 29: 161-168

Lucas RJ, Freedman MS, Munoz M, Garcia-Fernandez JM, Foster RG (1999) Regulation of the mammalian pineal by non-rod, non-cone, ocular photoreceptors. Science 284: 505-507

Lucas RJ, Douglas RH, Foster RG (2001) Characterization of an ocular photopigment capable of driving pupillary constriction in mice. Nat Neurosci 4: 621-626

Melyan Z, Tarttelin EE, Bellingham J, Lucas RJ, Hankins MW (2005) Addition of human melanopsin renders mammalian cells photoresponsive. Nature 433: 741-745

Minors DS, Waterhouse JM, Wirz-Justice A (1991) A human phase-response curve to light. Neurosci Lett 133: 36-40

Morita T, Tokura H (1998) The influence of different wavelengths of light on human biological rhythms. J Physio Anthropol Appl Human Sci 17: 91-96

Mukae H, Sato M (1992) The effect of color temperature of lighting sources on the autonomic nervous functions. Ann Physiol Anthrop 11: 533-538

National Aeronautics and Space Administration (2004) Bioastronautics Roadmap: A Risk Reduction Approach for
Human Spaceflight, NASA/SP-2004-6113

Noguchi H, Sakaguchi T (1999) Effect of illuminance and color temperature on lowering of physiological activity. J Physiol Anthropol Appl Human Sci 18: 117-123

Panda S, Sato TK, Castrucci AM, Rollag MD, DeGrip WJ, Hogenesch JB, Provencio I, Kay SA (2002) Melanopsin (Opn4) requirement for normal light-induced circadian phase-shifting. Science 298: 2213-2216

Panda S, Nayak SK, Campo B, Walker JR, Hogenesch JB, Jegla T (2005) Illumination of melatonin signaling pathway. Science 307: 600-604

Parry BL, Berga SL, Mostofi N, Sependa PA, Kripke DF, Gillin JC (1989) Morning versus evening bright light treatment of late luteal phase dysphoric disorder. Am J Psychiatry 146: 1215-1217

Pevet P, Heth G, Hiam A, Nevo E (1984) Photoperiod perception in the blind mole rat (Spalax ehrenbergi, Nehring): involvement of the Harderian gland, atrophied eyes, and melatonin. J Exp Zool 232: 41-50

Provencio I, Jiang G, De Grip WJ, Hayes WP, Rollag MD (1998) Melanopsin: an opsin in melanophores, brain, and eye. Proc Natl Acad Sci U S A 95: 340-345

Provencio I, Rodriguez IR, Jiang G, Hayes WP, Moreira EF, Rollag MD (2000) A novel human opsin in the inner retina. J Neurosci 20: 600-605

Provencio I, Rollag MD, Castrucci AM (2002) Photoreceptive net in the mammalian retina. Nature 415: 493

Qiu X, Kumbalasiri T, Carlson SM, Wong KY, Krishna V, Provencio I, Berson D (2005) Induction of photosensitivity by heterologous expression of melatonin. Nature 433: 745-749

Revell VL, Eastman CI (2005) How to trick mother nature into letting you fly around or stay up all night. J Biol Rhythms 20: 353-365

Revell VL, Arendt J, Terman M, Skene DJ (2005) Shortwavelength sensitivity of the human circadian system to phase-advancing light. J Biol Rhythms 20: 270-272

Revell VL, Arendt J, Fogg LF, Skene DJ (2006) Alerting effects of light are sensitive to very short wavelengths. Neurosci Lett 399: 96-100

Rollag MD (1996) Amphibian melanophores become photosensitive when treated with retinal. J Exp Zool 275: 20-26

Rollag MD, Berson DM, Provencio I (2003) Melanopsin, ganglion-cell photoreceptors, and mammalian photoentrainment. J Biol Rhythms 18: 227-234

Rosenthal NE, Sack DA, Gillin JC, Lewy AJ, Goodwin FK, Davenport Y, Mueller PS, Newsome DA, Wehr TA (1984) Seasonal affective disorder. A description of the syndrome and preliminary findings with light therapy. Arch Gen Psychiatry 41: 72-80

Ruberg FL, Skene DJ, Hanifin JP, Rollag MD, English J, Arendt J, Brainard GC (1996) Melatonin regulation in humans with color vision deficiencies. J Clin Endocrinol Metab 81: 2980-2985 
Sato M, Sakaguchi T, Morita T (2005) The effects of exposure in the morning to light of different color temperatures on the behavior of core temperature and melatonin secretion in humans. Biol. Rhythm Res 36: 287-292

Stewart KT, Eastman CI (1996) The light stuff: shiftwork, circadian rhythms, and manned spaceflight. In M Holick and A Kligman, eds. Biologic Effects of Light. Walter de Gruyter \& Co., Berlin, 340-347

Terman M, Lewy AJ, Dijk D-J, Boulos Z, Eastman CI, Campbell SS (1995) Light treatment for sleep disorders: consensus report. IV. sleep phase and duration disturbances. J Biol Rhythms 10: 135-147

Terman M, Terman JS, Ross DC (1998) A controlled trial of timed bright light and negative air ionization for treatment of winter depression. Arch Gen Psychiatry 55: 875-882

Terman J, Terman M, Lo E, Cooper T (2001) Circadian time of morning light administration and therapeutic response in winter depression. Arch Gen Psychiatry 58: 69-75

Thapan K, Arendt J, Skene DJ (2001) An action spectrum for melatonin suppression: evidence for a novel non-rod, noncone photoreceptor system in humans. J Physiol 535: 261-267.

Tuunainen A, Kripke DF, Endo T (2005) Light therapy for non-seasonal depression. The Cochrane Database of Systematic Reviews 2: CD004050

United States Congress Office of Technology Assessment (1991) Biological Rhythms: Implications for the Worker, U.S. Government Printing Office.

Warman VL, Dijk D-J, Warman GR, Arendt J, Skene DJ (2003) Phase advancing human circadian rhythms with short wavelength light. Neurosci Lett 342: 37-40

Webb SM, Champney TH, Lewinski AK, Reiter RJ (1985) Photoreceptor damage and eye pigmentation: influence on the sensitivity of rat pineal $N$-acetyltransferase activity and melatonin levels to light at night. Neuroendocrinology 40: 205-209

Whitson PA, Putcha L, Chen YM, Baker E (1995) Melatonin and cortisol assessment of circadian shifts in astronauts before flight. J Pineal Res 18: 141-147

Wright HR, Lack LC, Partridge KJ (2001) Light emitting diodes can be used to phase delay the melatonin rhythm. J Pineal Res 31: 350-355

Yasukouchi A, Ishibashi K (2005) Non-visual effects of the color temperature of fluorescent lamps on physiological aspects in humans. J Physiol Anthropol Appl Human Sci 24: 41-43

Yasukouchi A, Yasukouchi Y, Ishibashi K (2000) Effects of color temperature of fluorescent lamps on body temperature regulation in a moderately cold environment. J Physiol Anthropol Appl Human Sci 19: 125-134

Yoshimura T, Ebihara S (1996) Spectral sensitivity of photoreceptors mediating phase-shifts of circadian rhythms in retinally degenerate $\mathrm{CBA} / \mathrm{J}(\mathrm{rd} / \mathrm{rd})$ and normal $\mathrm{CBA} / \mathrm{N}$ $(+/+)$ mice. J Comp Physiol [A] 178: 797-802

This article was presented at the 8th International Congress of Physiological Anthropology, 2006 (ICPA 2006), in Kamakura, Japan.

Received: September 30, 2006

Accepted: November 29, 2006

Correspondence to: George C. Brainard, Ph.D., Department of Neurology, Thomas Jefferson University, 1025 Walnut Street, Suite 507, Philadelphia, PA 19107

Phone: 215-955-7644

Fax: 215-923-7588

e-mail: george.brainard@jefferson.edu 